\title{
DISCOLOURATION OF HEAT-TREATED FAST-GROWING EUCALYPTUS WOOD EXPOSED TO NATURAL WEATHERING
}

\author{
RAFAEL DE AVILA DELUCIS, RAFAEL BELTRAME and DARCI ALBERTO GATTO \\ Post-Graduation Program in Materials Science and Engineering (PPGCEM), \\ Federal University of Pelotas, R. Gomes Carneiro 1, 96075-630, Pelotas, RS, Brazil \\ $\bowtie$ Corresponding author: Rafael de Avila Delucis, r.delucis@hotmail.com
}

Received September 18, 2019

\begin{abstract}
To heat-treat is one of the main alternatives to improve wood performance in outdoor uses. This study aimed to evaluate the discolouration of a heat-treated fast-growing eucalyptus wood exposed to natural weathering tests. Wood samples were cut from a young eucalyptus forest located in Southern Brazil. Thermal treatments were performed in an oven without forced air circulation, according to four combined settings of temperature (i.e. $180{ }^{\circ} \mathrm{C}$ and $220{ }^{\circ} \mathrm{C}$ ) and time (i.e. $3 \mathrm{~h}$ and $6 \mathrm{~h}$ ). The discolouration of the decayed wood was accessed according to the CIELab method. The heat-treatment improved the weathering performance of the eucalyptus wood. Compared to the natural colour of the thermally treated wood, the weathering tests caused fading and greying in its tones. Regarding the treatment parameters, the samples heat-treated during $6 \mathrm{~h}$ presented promising results, demonstrating that such treatment may be a useful tool for wood surface protection.
\end{abstract}

Keywords: wood biodeterioration, thermoretification, decay test, field test, eco-friendly treatment

\section{INTRODUCTION}

Wood deterioration is attributed to several biotic and abiotic factors and is the main concern when wood products are designed for outdoor environments. The wood susceptibility to these agents is called as its weathering resistance and has been mainly investigated using colour measurements. In this sense, the main abiotic factors are: moisture content of wood, temperature, sunlight, presence of ozone and pollution (i.e. presence of some xenobiotic organopollutants capable of catalyzing enzymatic processes of certain xylophagous fungi). On the other hand, regarding biodegradation in woods, fungi and insects are the main agents.

According to Delucis and coworkers, wood weathering is a complex mechanism, but can be briefly described by the effects related to photodegradation and fungal attack. ${ }^{1}$ Degradation starts due to electromagnetic waves from the sun, which are absorbed by certain chemical groups present in wood, such as carbonyls, carboxyls, quinones, and peroxides, leading to depolymerization processes in lignin, extractives, among others. Meanwhile, the generation of free radicals and weakening of the overall ligno- cellulosic structure may also occur. Moreover, drying gradients may lead to surface cracks, exposing some wood regions rich in polysaccharides and lignin, and the wood surface becomes susceptible to xylophagous fungi proliferation. Afterwards, degraded compounds are leached by rain and wind actions. ${ }^{2,3}$

Regarding climate conditions, the higher the solar radiation, the higher the photodegradation effect. ${ }^{3}$ Also, warm climates coupled with a certain range of relative humidity in the air are offer suitable conditions for the development of most xylophagous fungi. Due to the great variability in both biotic and abiotic factors, wood performance must be evaluated for every environment it will be exposed to and, for this reason, it is very hard to use artificial tests with reliability. This way, the service life of wood products is preferably evaluated using field tests or some other outdoor tests. ${ }^{1,3}$

For instance, Mattos and coworkers described three untreated Brazilian eucalypt woods exposed to natural weathering and reported that the main effects were related to significant discolouration, marked by a greyish colour, especially after 135 
days of exposure. ${ }^{4}$ They also reported that each of their eucalypts showed a different damage level. Delucis and coworkers studied four untreated Brazilian eucalypts exposed to field tests and reported that they became dark and opaque. ${ }^{3}$ Also, both natural yellow and red pigments were progressively lost over the aging tests. These important findings also indicate a great usefulness of colourimetry to evaluate wood weathering. Indeed, colour is among the main perceptual attributes to stimulate consumption.

In their work, Magalhães and coworkers affirmed that the decay resistance of their eucalypt (Corymbia citriodora) wood was smaller in Southern Brazil than in Australian environment. ${ }^{5}$ According to them, the quick development of fast-growing eucalypts in Brazil leads to an increased proportion in sapwood, which is more susceptible to degradation than heartwood. It can also be stated about juvenile and mature woods. Because of that, even timbers with a well-known reputation of high durability in Europe or North America may require preservative treatments to be used in tropical countries.

In this sense, many treatments have been proposed in order to minimize weathering effects on wood surface, with some promising results already reported. These treatments include: thermal treatments, ${ }^{6,7}$ acetylation, ${ }^{8}$ surface coatings, ${ }^{2}$ manufacture of wood composites with wood flour, ${ }^{9}$ wood fiber, ${ }^{10}$ and in situ polymerization, ${ }^{11}$ among other chemical modifications. ${ }^{10,12,13}$

In comparison with other treatments, thermal treatment is an eco-friendly treatment capable of improving many wood features without using chemicals. The already reported improvements for wood properties include: dimensional stability, ${ }^{14}$ decay resistance, ${ }^{15}$ colour stability ${ }^{6,14}$ surface hydrophobicity, ${ }^{15}$ surface regularity, ${ }^{14,16}$ among others. Most of these results were achieved by partial degradation of amorphous segments and/or progressive modifications in wood extractives, which may depend on a correct fit of certain treatment parameters, such as time, temperature, pressure, atmosphere composition (e.g. $\mathrm{O}^{2}$ or $\mathrm{N}^{2}$ ), open or closed systems and humid or dry systems. ${ }^{17}$ For instance, to modify the atmosphere composition is a way to control any thermal event of interest.

Currently, the use of thermal treatments is constantly growing due to the scarcity of naturally qualified woods. Industrial procedures apply high technologies, in which time and temperature are meticulously defined. ThermoWood $\AA$, Plato®Wood, Le Bois Perdure ${ }^{\circledR}$ and Retification ${ }^{\circledR}$ can be cited as prominent procedures. ${ }^{17}$ For instance, the wood subjected to the ThermoWood $\AA$ treatment is recommended for floors, external doors and furniture for bathroom, saunas and gardens. At the moment, Le Bois Perdure ${ }^{\circledR}$ is under development by a partnership between a private company and a university in Canada. The applications of Plato®Wood include: façade cladding, window frames, windows and doors and sound barriers. The latter treatment is designed for fast-growing woods to produce a minimal ecological footprint.

In this context, to use fast-growing species, such as eucalyptus, in investigations on this topic becomes interesting, due to some of their known advantages, such as fast growth, good mechanical properties, pesticide resistance, high adaptability, management culture consolidated, among others. The present study aimed to evaluate the discolouration of thermally treated eucalyptus woods exposed to Brazilian environment.

\section{EXPERIMENTAL}

\section{Raw material selection}

17 year old Eucalyptus grandis trees were selected from a homogeneous forest planted with an initial spacing of $3 \mathrm{~m} \times 1.7 \mathrm{~m}$. This forest is located in the city of Capivari do Sul/Brazil $\left(30^{\circ} 14^{\prime} 10^{\prime \prime}\right.$ S, $50^{\circ} 19^{\prime} 55^{\prime}$ "W). This city presents a warm and temperate climate (Cfa according to Köppen's classification) and its historical averages for temperature and annual rainfall are $18.9{ }^{\circ} \mathrm{C}$ and 1492 $\mathrm{mm}$, respectively. From each felled tree, a $3.5 \mathrm{~m}$ long baseline $\log$ was obtained at a height of $10 \mathrm{~cm}$ from the ground. The wood logs were transformed into $10 \mathrm{~cm}$ thick central planks and then subjected to outdoor drying for about three months. Prismatic wood samples were cut with the following dimensions: $5.0 \times 5.0 \times$ $2.5 \mathrm{~cm}^{3}$ (length $\times$ width $\times$ thickness). Afterwards, the samples were stored in a climatic chamber under $65 \%$ $\mathrm{RH}$ and $20^{\circ} \mathrm{C}$ temperature until reaching equilibrium moisture content.

\section{Thermal treatments}

Thermal treatments were performed using an electric oven without forced air circulation and a heating rate of $2{ }^{\circ} \mathrm{C} \cdot \mathrm{min}^{-1}$. As shown in Table 1, samples were treated at $180{ }^{\circ} \mathrm{C}$ and $220{ }^{\circ} \mathrm{C}$ for $3 \mathrm{~h}$ and $6 \mathrm{~h}$, whereas four combinations between these parameters (temperature and treatment time) were defined. Averages for both final mass loss and apparent density were also included in Table 1. 


\section{Weathering test}

Seven samples per group were subjected to weathering. The weathering tests were performed over one year (almost 360 days), beginning on March 20, 2014 and finishing on February 20, 2015. Samples were collected every 120 days, totalling three samplings. The samples were kept on weathering racks with a $45^{\circ}$ slope direction towards south west. This experiment took place in the city of Pelotas/Brazil, which has GPS coordinates of $31^{\circ} 46^{\prime} 40^{\prime \prime}, \mathrm{S}$ and $52^{\circ} 21^{\prime} 05^{\prime \prime} \mathrm{W}$ and an elevation of $7 \mathrm{~m}$. It also presents a warm and temperate climate (Cfa according Köppen's classification) with historical averages for temperature and annual rainfall of $18{ }^{\circ} \mathrm{C}$ and $1402 \mathrm{~mm}$, respectively. The Scheffer Index was calculated for all the weathering tests and reached $168.35 .{ }^{18}$ Figure 1 displays the mean monthly average temperature $\left({ }^{\circ} \mathrm{C}\right)$ and the mean number of days per month with $0.25 \mathrm{~mm}$ or more of precipitation, which were published by EMBRAPA (Brazilian company for agricultural research) and used to obtain the Scheffer Index. ${ }^{19}$

Table 1

Treatment parameters and data for mass loss and apparent density

\begin{tabular}{lccccc}
\hline Treatments & Control & T1 & T2 & T3 & T4 \\
\hline Temperature $\left({ }^{\circ} \mathrm{C}\right)$ & 20 & 180 & 180 & 220 & 220 \\
Time $(\mathrm{h})$ & - & 3 & 6 & 3 & 6 \\
Mass loss $(\%)$ & - & $10.48^{ \pm 1.69}$ & $17.47^{ \pm 7.61}$ & $11.27^{ \pm 1.05}$ & $19.94^{ \pm 7.37}$ \\
$\begin{array}{l}\text { Apparent density } \\
\left(\mathrm{g} . \mathrm{cm}^{-3}\right)\end{array}$ & $0.534^{ \pm 0.04}$ & $0.515^{ \pm 0.05}$ & $0.486^{ \pm 0.03}$ & $0.506^{ \pm 0.01}$ & $0.463^{ \pm 0.02}$ \\
\hline
\end{tabular}

Standard deviations are superscripts

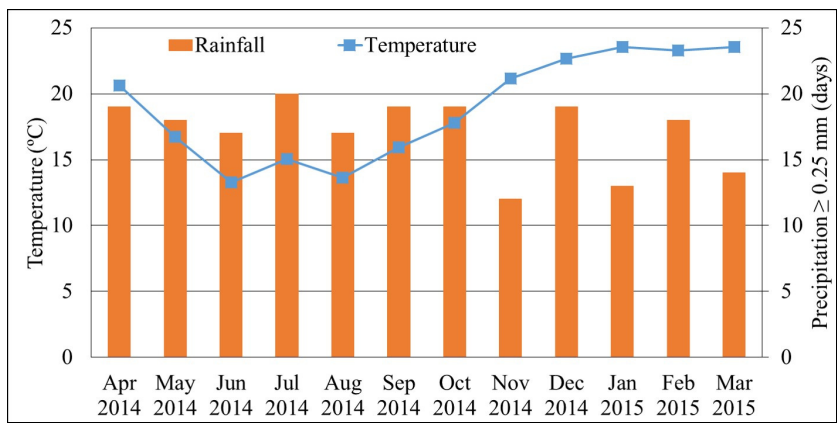

Figure 1: Climate conditions during natural weathering tests

\section{Evaluation of discolouration}

Discolouration of thermally modified and untreated wood samples exposed to weathering was evaluated using a spectro-colorimeter (CR-400 model; $10^{\circ}$ standard observer; D65 standard illuminant), following the CIELab method. This system is characterized by three parameters, namely $L^{*}, a^{*}, b^{*}$, whereas $+L^{*}$ represents brightness, $-\mathrm{L}^{*}$ represents darkness, $+\mathrm{a}^{*}$ represents redness, $-\mathrm{a}^{*}$ represents greenness, $+\mathrm{b}^{*}$ represents yellowness and $-b^{*}$ represents blueness. Colour parameters were measured at five different locations for each sample. Then, total colour change $\left(\Delta \mathrm{E}^{*}\right)$ was calculated from $\Delta \mathrm{L}^{*}, \Delta \mathrm{a}^{*}$ and $\Delta \mathrm{b}^{*}$, according to previous studies. ${ }^{1,3}$

\section{RESULTS AND DISCUSSION}

Colour of wood before the weathering test

Table 2 shows the natural eucalypt colour (control group) and its colour modification caused by the thermal treatments, which was significantly changed by each thermal treatment and regarding all colour parameters. About the process parameters (temperature and treatment time), the variation of the temperature from $180{ }^{\circ} \mathrm{C}$ to 220 ${ }^{\circ} \mathrm{C}$ caused a decrease in $L^{*}$ and $h$ after $3 \mathrm{~h}$, which were of 14.2 and $2.9 \%$, respectively. Among the colour parameters, only $\mathrm{L}^{*}$ did not decrease in a comparison between treatment durations of $3 \mathrm{~h}$ and $6 \mathrm{~h}$, for the same temperature. This indicates that $\mathrm{L}^{*}$ was the main colour parameter affected during the first hours of treatment, although it was nearly followed by $h$ (which is due to the direct relation between these two parameters). After $3 \mathrm{~h}$, both these colour parameters presented a stabilization. 
RAFAEL DE AVILA DELUCIS et al.

Table 2

Colour of heat-treated and untreated wood samples

\begin{tabular}{lccccc}
\hline Treatments & $L^{*}$ & $a^{*}$ & $b^{*}$ & $C^{*}$ & $H$ \\
\hline Control & $77.60^{ \pm 4.68} \mathrm{~d}$ & $7.31^{ \pm 1.57} \mathrm{c}$ & $18.02^{ \pm 1.26} \mathrm{~d}$ & $19.47^{ \pm 1.66} \mathrm{c}$ & $68.10^{ \pm 3.28} \mathrm{e}$ \\
$180^{\circ} \mathrm{C}, 3 \mathrm{~h}$ & $55.00^{ \pm 6.18} \mathrm{c}$ & $8.51^{ \pm 1.06} \mathrm{~d}$ & $16.65^{ \pm 2.49} \mathrm{c}$ & $18.74^{ \pm 2.36} \mathrm{c}$ & $62.66^{ \pm 4.25} \mathrm{~d}$ \\
$180^{\circ} \mathrm{C}, 6 \mathrm{~h}$ & $32.04^{ \pm 1.77} \mathrm{a}$ & $5.92^{ \pm 1.19} \mathrm{~b}$ & $8.21^{ \pm 2.40} \mathrm{~b}$ & $10.14^{ \pm 2.62} \mathrm{~b}$ & $53.48^{ \pm 3.22} \mathrm{~b}$ \\
$220^{\circ} \mathrm{C}, 3 \mathrm{~h}$ & $47.14^{ \pm 2.45} \mathrm{~b}$ & $9.29^{ \pm 0.70} \mathrm{~d}$ & $16.80^{ \pm 2.23} \mathrm{c}$ & $19.22^{ \pm 2.18} \mathrm{c}$ & $60.84^{ \pm 2.53} \mathrm{c}$ \\
$220^{\circ} \mathrm{C}, 6 \mathrm{~h}$ & $30.19^{ \pm 0.46} \mathrm{a}$ & $4.06^{ \pm 0.72} \mathrm{a}$ & $4.46^{ \pm 1.26} \mathrm{a}$ & $6.04^{ \pm 1.40} \mathrm{a}$ & $46.99^{ \pm 3.59} \mathrm{a}$ \\
F-ratio & $863.86^{* *}$ & $126.77^{* *}$ & $322.64^{* *}$ & $309.19^{* *}$ & $203.55^{* *}$
\end{tabular}

Standard deviations are superscripts and different letters in columns represent significantly different averages according to Fisher tests

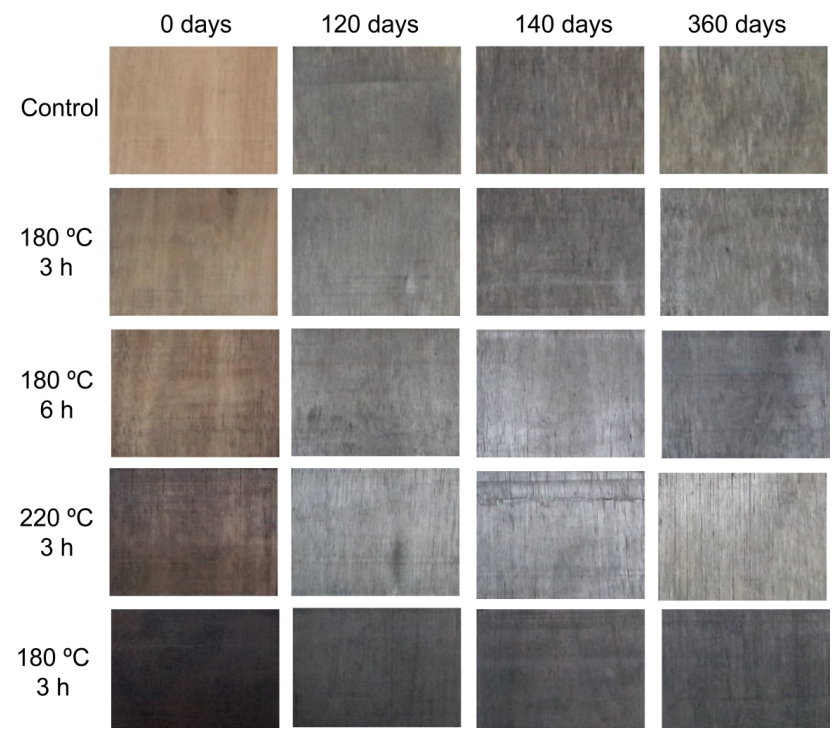

Figure 2: Photographs of wood samples before and after weathering tests

In their work, Zanuncio and coworkers treated a Brazilian eucalypt (Eucalyptus pellita) in the form of powder, applying $170{ }^{\circ} \mathrm{C}$ and $200{ }^{\circ} \mathrm{C}$ for $3 \mathrm{~h} \cdot{ }^{20}$ In comparison with their untreated samples, they found $\mathrm{L}^{*}$ changes of $18.18 \%$ and $29.19 \%$ for $170{ }^{\circ} \mathrm{C}$ and $200{ }^{\circ} \mathrm{C}$, respectively. Cademartori and coworkers treated a Brazilian eucalypt (Eucalyptus grandis) at $180{ }^{\circ} \mathrm{C}, 200{ }^{\circ} \mathrm{C}, 220{ }^{\circ} \mathrm{C}$ and $240{ }^{\circ} \mathrm{C}$ for $4 \mathrm{~h}$ and, in comparison with their untreated samples, found that $\mathrm{L}^{*}$ levels decreased by $30.4 \%, 41.0 \%, 51.9 \%$ and $54.1 \%$, respectively. ${ }^{6}$ These changes are similar to those obtained in the present study. These colour modifications are attributed to an intimate relation of the wood colour with both the content and composition of wood extractives. ${ }^{21}$ In this sense, the darkened colour attributed to thermally treated woods is attributed to condensation, oxidation and volatilization of some organic extractives, which occur from $130{ }^{\circ} \mathrm{C}$ to $250{ }^{\circ} \mathrm{C}$.,22

\section{Discolouration of wood samples}

Figure 2 presents photographs of the studied samples. According to Figure 3, for the untreated samples, the discolouration was higher up to 120 days $(-16.8 \%)$, which can be noticed with the naked eye. ${ }^{23}$ The colour depreciation presented a stabilization after 120 days (i.e. a variation lower than 6\%). Delucis and coworkers found a similar behaviour for pristine eucalypt samples, attributing the initial colour depreciation to reactions in the chromophore groups belonging to lignin and extractives. ${ }^{23}$

Analysing the thermally modified samples based on their $\mathrm{L}^{*}$ levels, an increase up to 120 days was found and, after that, there was a stabilization until 360 days. However, comparing heat-treated and untreated samples, the opposite behaviour was noted until 120 days, which is higher for the treatments performed for $6 \mathrm{~h}(47.7$ and $40.5 \%$ for $220{ }^{\circ} \mathrm{C}$ and $180{ }^{\circ} \mathrm{C}$, respectively), than for the treatments carried out during $3 \mathrm{~h}$ 
(11.2 and $0.1 \%$, for $220{ }^{\circ} \mathrm{C}$ and $180{ }^{\circ} \mathrm{C}$, respectively). Thus, the heat-treated samples showed a gradual loss in their dark tones, in a way that the higher the initial darkness, the higher the loss in dark tones.

Cademartori and coworkers evaluated three pristine Brazilian eucalypt woods when subjected to field tests over 240 days and found decreases in $\mathrm{L}^{*}$ averages of $27.53 \%, 25.17 \%$ and $21.93 \%$ for Eucalyptus cloeziana, Eucalyptus grandis and Eucalyptus saligna, respectively. ${ }^{24}$ Delucis and coworkers monitored the weathering phenomena occurring in two pristine Brazilian eucalypt woods, namely Corymbia citriodora and Eucalyptus tereticornis, during 225 days. ${ }^{3}$ They found $\mathrm{L}^{*}$ decreases of $15.73 \%$ and $29.06 \%$ for Corymbia citriodora and Eucalyptus tereticornis, respectively. These findings indicate that the averages presented in the present work are larger than those reported in some previously published studies, which is probably due to differences in the used weathering tests. Actually, these previous studies were conducted using field tests

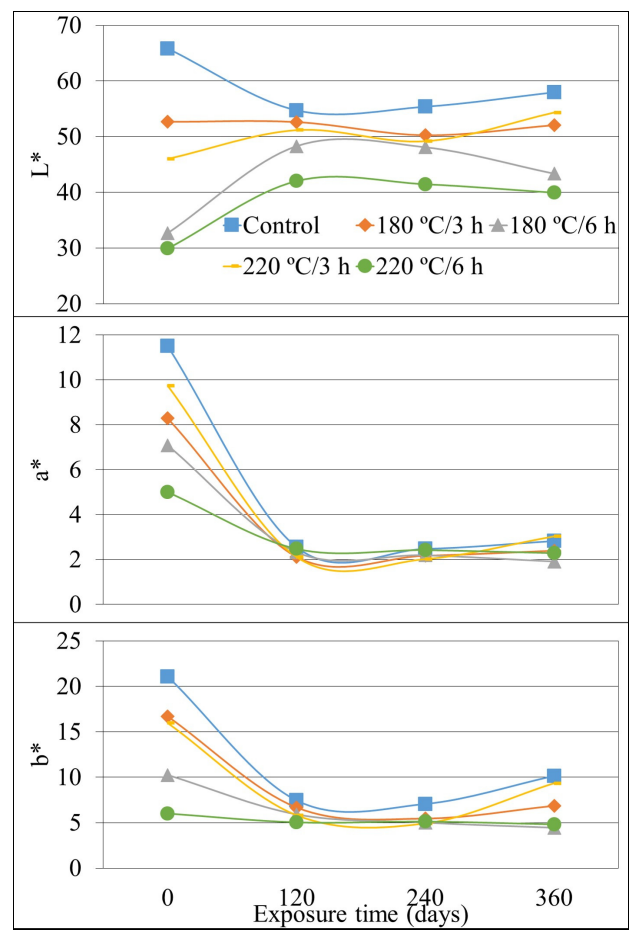

Figure 3: Brightness $\left(L^{*}\right)$, green-red coordinate $(a *)$ and blue-yellow coordinate $\left(b^{*}\right)$ levels as a function of exposure time and the samples used in the present work were aged on weathering racks, in which there is a maximized incidence of solar radiation.

Regarding the other colour parameters shown in Figure $3\left(a^{*}\right.$ and $\left.b^{*}\right)$, a similar behaviour was found comparing untreated and heat-treated samples, indicating losses in redness and yellowness occurred in all wood samples, although the losses were higher in the untreated samples. Comparing the thermal treatments, the samples treated for $6 \mathrm{~h}$ presented more stable colour parameters over one year, than the other wood samples (treated for $3 \mathrm{~h}$ ). Similar results were reported in the literature for pristine eucalypts. ${ }^{1,3,4}$

Compared with $\mathrm{a}^{*}$ and $\mathrm{b}^{*}$ levels, $\mathrm{C}^{*}$ presented a similar behaviour (Fig. 4) and its variation seems to be attributed to previously discussed causes (degradation of lignin and extractives). On the other hand, based on $h$ levels, it becomes clear that there was an increased discolouration in the darkened samples (i.e. treated for $6 \mathrm{~h}$ ), as discussed above for the $\mathrm{L}^{*}$ levels.

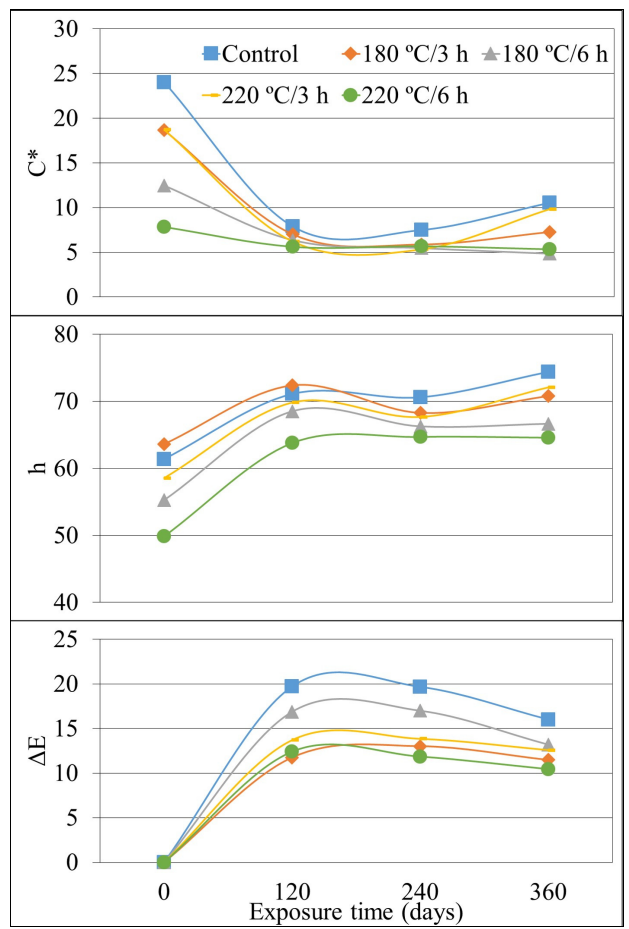

Figure 4: Levels of Chroma $\left(C^{*}\right)$, hue angle $(h)$ and colour change $(\Delta \mathrm{E})$ as a function of exposure time 
RAFAEL DE AVILA DELUCIS et al.

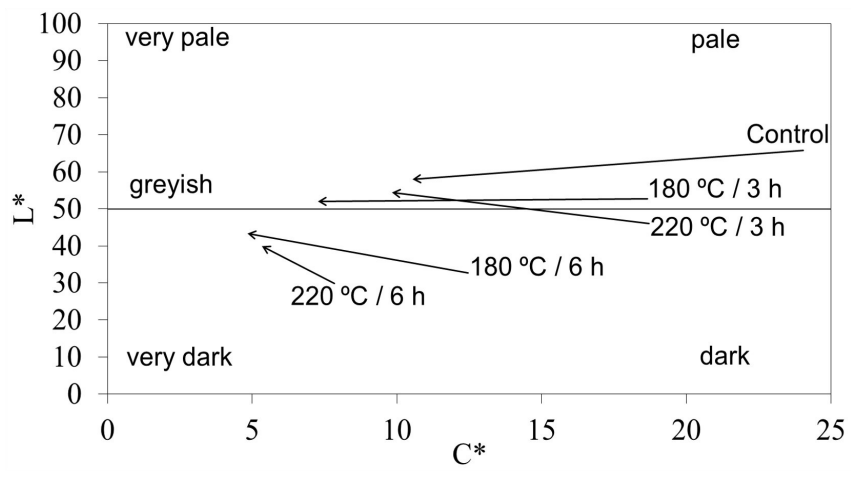

Figure 5: Chroma diagrams for wood samples after 360 days of weathering

Although the samples treated for $6 \mathrm{~h}$ presented the highest discoloration over the exposure time, they still remained darker compared to the others. The differences found for the more aggressive treatments are probably related to the thermal degradation of some chemical groups belonging to lignin, which occurs up to $240{ }^{\circ} \mathrm{C}$.

The $\Delta \mathrm{E}$ levels also confirm the highest weathering performance of the samples treated at $220{ }^{\circ} \mathrm{C}$ for $6 \mathrm{~h}$. Besides, the found colour changes were notable with the naked eye after 120 days of exposure, since all the groups reached more than $10 \%{ }^{23}$ From the combination of $\mathrm{L}^{*}$ and $\mathrm{C}^{*}$ averages shown in Figure 5 (Chroma diagrams), $\mathrm{L}^{*}$ levels increased, while $\mathrm{C}^{*}$ levels presented strong decreases. Based on that, it is clear that thermally treated and untreated wood samples underwent a weathering mechanism, in which fading and greying of their original colours occurred. The vectors shown in Figure 5 also clearly confirm that the untreated samples presented the highest discoloration. Also, according to the Chroma diagrams, the samples treated at $220{ }^{\circ} \mathrm{C}$ for $6 \mathrm{~h}$ presented the highest colour stability.

\section{CONCLUSION}

Comparing the process parameters, the effect of the treatment time on colour parameters was more significant than that of the temperature. The samples heat-treated for $6 \mathrm{~h}$ presented higher susceptibility to weathering effects. Although more discoloured, these samples showed the highest darkness after the weathering tests. The weathering caused fading and greying in the natural colour of the thermally treated wood. To treat wood thermally for $6 \mathrm{~h}$ may be a useful tool for protecting wood surface during exposure to outdoor environments.
ACKNOWLEDGMENTS: The authors would like to thank CAPES for supporting this work.

\section{REFERENCES}

1 R. A. Delucis, P. H. G. de Cademartori, A. L. Missio and D. A. Gatto, Maderas: Cienc. Tecnol., 18, 33 (2016), http://doi.org/10.4067/S0718221X2016005000004

J. Creemers, M. Meijer, T. Zimmermann and J. Sell, Eur. J. Wood Wood Prod., 60, 411 (2002), https://doi.org/10.1007/s00107-002-0338-5

R. A. Delucis, R. H. Diaz, J. Labidi and D. A. Gatto, Maderas: Cienc. Tecnol., 18, 133 (2016), http://doi.org/10.4067/S0718-221X2016005000014

4 B. D. Mattos, P. H. G. Cademartori, T. V. Lourençon and D. A. Gatto, Int. Wood Prod. J., 5, 33 (2013), http://doi.org/10.1179/2042645313y.0000000035

5 W. L. E. Magalhães, B. D. Mattos and A. L. Missio, Int. Biodeterior. Biodegrad., 74, 124 (2012), https://doi.org/10.1016/j.ibiod.2012.05.024

6 P. H. G. de Cademartori, E. Schneid, D. A. Gatto, D. M. Stangerlin and R. Beltrame, Maderas: Cienc. Tecnol., 15, 57 (2013), http://doi.org/10.4067/s0718$221 \times 2013005000005$

P. H. G. de Cademartori, P. S. B. dos Santos, L. Serrano, J. Labidi and D. A. Gatto, Ind. Crop. Prod., 45, $360 \quad$ (2013), http://doi.org/10.1016/j.indcrop.2012.12.048

8 P. D. Evans, N. L. Owen, S. Schmid and R. D. Webster, Polym. Degrad. Stabil., 76, 291 (2002), https://doi.org/10.1016/S0141-3910(02)00026-5

9 S. Butylina, M. Hyvärinen and T. Kärki, Eur. J. Wood Wood Prod., 70, 719 (2012), https://doi.org/10.1007/s00107-012-0606-y

10 Y. Zhang, S. Y. Zhang and P. Choi, Eur. J. Wood Wood Prod., 66, 267 (2008), https://doi.org/10.1007/s00107-008-0246-4

11 B. D. Mattos, A. L. Missio, P. H. G. Cademartori, D. A. Gatto and W. L. E. Magalhães, Maderas: Cienc. Tecnol., 18, 113 (2016), http://doi.org/10.4067/s0718$221 \times 2016005000012$ 
12 I. U. H. Bhat, H. P. S. A. Khalil, K. B. Awang, I. O. Bakare and A. M. Issam, Mater. Des., 31, 4363 (2010), https://doi.org/10.1016/j.matdes.2010.03.045

13 B. Lesar, M. Pavlic, M. Petric, A. S. Skapin and M. Humar, Polym. Degrad. Stabil., 96, 1271 (2011), https://doi.org/10.1016/j.polymdegradstab.2011.04.006

14 E. Schneid, P. H. G. Cademartori and D. A. Gatto, Maderas: Cienc. Tecnol., 16, 413 (2014), http://doi.org/10.4067/s0718-221x2014005000033

15 Z. Šušteršic, A. Mohareb, M. Chaouch, M. Pétrissans, M. Petrič et al., Polym. Degrad. Stabil., 95, 94 (2010), https://doi.org/10.1016/j.polymdegradstab.2009.10.013

16 G. P. M. Palermo, J. V. F. Latorraca, L. F. Moura, A. M. Nolasco, A. M. Carvalho et al., Maderas: Cienc. Tecnol., 16, 03 (2014), https://doi.org/10.4067/S0718221X2014005000001

17 R. A. Delucis, S. F. Machado, A. L. Missio and D. A. Gatto, J. Indian Acad. Wood Sci., X, 1 (2019), https://doi.org/10.1007/s13196-019-00237-w

18 T. C. Scheffer, Forest Prod. J., 21, 25 (1971), http://agris.fao.org/agris-

search/search.do?recordID=US201302242092

19 Meteorological data for Pelotas/RS (NMR):

$<$ http://agromet.cpact.embrapa.br>, accessed in $29 / 06 / 2019$
20 A. J. V. Zanuncio, A. G. Carvalho, M. T. de Souza, C. M. Jardim, A. de C. O. Carneiro et al., Maderas: Cienc. Tecnol., 17, 857 (2015), http://doi.org/10.4067/S0718-221X2015005000074

21 R. Moya, R. S. Fallas, P. J. Bonilla and C. Tenorio, Molecules, $\quad \mathbf{1 7}, \quad 3639 \quad$ (2012), https://doi.org/10.3390/molecules 17043639

22 Y. Cao, F. Chan, Y. H. Chui and H. Xiao, Bioresources, $\quad 7,4109 \quad$ (2012), https://ojs.cnr.ncsu.edu/index.php/BioRes/article/view/ BioRes_07_3_4109_Cao_CCX_Characterization_Flax _Fiber_Alkaline_Enzyme_Steam

${ }^{23}$ R. A. Delucis, R. H. Diaz, S. C. Amico, J. Labidi and D. A. Gatto, Cellulose Chem. Technol., 51, 889 (2017),

http://www.cellulosechemtechnol.ro/pdf/CCT910(2017)/p.889-898.pdf

24 P. H. G. de Cademartori, A. L. Missio, B. D. Mattos and D. A. Gatto, Maderas: Cienc. Tecnol., 17, $799 \quad$ (2015), http://doi.org/10.4067/s0718- 